\title{
TRADE REVIVAL IN THE LUMBER INDUSTRY
}

\author{
By JNo. E. Williams, \\ Editor "Lumber Trade Journal," New Orleans.
}

To be of public service a discussion of present conditions of the lumber industry must deal primarily with those phases of it least generally or not at all understood. It is a curious fact that the American lumber industry, although ranking fourth in the country, is very largely an object of public misinformation, indifference or ignorance. It rarely happens that wood products are included in the commercial reviews appearing in secular newspapers, and when discussed at all, results are generally misleading and often grotesquely absurd. The reason for this is perhaps not far to find. Lumbering operations are generally remote from the centers of affairs and familiar to those immediately interested only. To the average person, wood is in a manner not unlike water, it seldom excites little conscious heed until missed. Since earliest times this human intimacy with wood has begun in the cradle and ended in the coffin. In the interval it is inseparable from practically all of the domestic economies-houses, barns, furniture, vehicles, walks, railroad equipment, boats and the thousand and one minor articles designed for as many practical and ornamental purposes. As a result timber consumption has been and still is on a scale of inconceivable magnitude.

The white pine forests in the lake region or in the old Northwest for upwards of fifty years have been supplying much of the country lying between them and certain sections of the East. They were at one time regarded as practically inexhaustible, but are today largely depleted. In those days, too, this supposed superabundance of timber naturally operated to depreciate commercial values and to restrict development to the largest and choicest trees only. In the meanwhile the rate of consumption has kept pace with the fabulous growth of the country and foreign requirements, until, at the present time, dependence for wood products is upon all the wooded regions of the country, notably, besides the older sections, the southern and Pacific coast states. The larger residue of stand-

(512) 
ing timber is in the latter, but the South is supplying a larger share of domestic and foreign requirements.

The entire wooded area of the United States has been estimated to be, according to available data, 550,000,000 acres. This, like most other kindred statistical estimates-nothing of the sort has ever been systematically verified-conveys at best a doubtful sense of the reality. An example of a sort was that of an article appearing years ago in a popular magazine on the timber resources of Mississippi. The article was well written and superbly illustrated. In a general way it possessed educational value except in the all important particular of showing the timber at the time standing in the state, which, it was gravely stated, amounted to "I8,000,000 feet!" There are scores of mills in the state that cut as much or more every year. Whether the error was typographical or not, the absurdity of the estimate would naturally in either case have excited in the editor or average reader no clearer or more intelligent consciousness than $18,000,000,000$ would have done. As a matter of fact, it is doubtful if one of ten citizens could, if suddenly called upon, define the exact meaning of a standard foot of lumber. The nine uninitiated probably do not know that this standard means a piece twelve inches square and one inch thick. Whether applied to sawed products an inch in thickness, or any dimension including the heaviest timbers, this standard unit of measurement is uniformly the basis of all computations.

The woods of commerce in this country embrace principally the pines or other species known as conifers, cypress, in a class of its own, exclusively indigenous to the South, more particularly in the gulf states, and the hardwoods which, speaking tuntechnically, embrace in great number and variety all of the woods of commerce with deciduous foliage. This classification is anomalous in that some of the so-called hardwoods are softer and lighter than one species of the pines indigenous to the gulf states and known as longleaf yellow pine, which weighs as much as, and possesses the tensile strength of, even certain of the more sturdy hardwoods. The weight of wood products varies of course according to the texture, general character and condition of any given example. If rough and lately cut green, weights range from 3,500 to 6,000 pounds per thousand feet, or, of course, three and one-half to six pounds per standard foot. If dry and surfaced, or planed or dressed-all 
terms signifying the smoothing process-the weight is reduced to say from 2,000 pounds upward, according to the character and dimensions of the material. An average carload of dry lumber amounts to about 20,000 feet. The importation of foreign woods is largely restricted to mahogany and other tropical and costly cabinet species and the coarser grades of Canadian white pine. The laity, so to speak, should find these details useful in connection with lumber statistics and justified, in a prefatory way here, on the ground that the present discussion may to a limited extent serve an educational purpose.

\section{Degree of Recovery from Recent Depression}

The money panic of 1907 promptly and sharply undermined the lumber industry and to an extent believed to have been equaled in the case of no other commodity of like or greater importance. The crisis interrupted a period of activity and prosperity unprecedented in the history of the industry. The volume of trade and prices had attained proportions previously unexampled and were on a level with the then inflated state of trade generally. From prices thus without precedent and a demand scarcely less phenomenal, both fell off until producers found themselves seriously embarrassed and perplexed. The situation called for immediate and decided curtailment, but the mill men were slow to adopt either policy. The general belief was that the revulsion would be short lived and operating crews must be cared for. In this the American saw mill contingent is peculiar, for though largely incorporated, its votaries are unfailingly humane. In some quarters the trade kept up a steady and not seriously shrunken volume of business. At first not only building operations underwent a marked falling off, but the railroads whose requirements had previously absorbed from thirty to forty per cent of the entire forest products of the country, abruptly withdrew from the market and until recently kept out of it almost entirely. Other branches of consuming industry, notably furniture and vehicle factories, were affected, and there was general and depressing shrinkage of demand and an even greater per cent of falling off in prices. This outlines, briefly, the situation during 1908 and the first half of 1909 . In the meanwhile the farming contingent, for the most part blissfully exempt from the ravages of hard times, continued fairly good customers, and with the revival of 
building operations to really unprecedented proportions, the reduction in consumption ceased and the industry was saved from disastrous stagnation. When later, about a few months ago, the railroads began cautiously to place orders for material long needed for neglected repairs and reconstruction, the clouds broke and brightness began to shine through. The factors to-day lacking to restore ante-panic conditions include, most notably, still greater activity in railroad requirements, more conservative production and greater confidence in the future behavior of markets.

\section{Tariff Legislation}

The prices of lumber preceding the panic while publicly regarded as abnormally high and in point of fact comparatively higher than at any former period, were not relatively excessive. It is a matter of repeatedly demonstrated fact that during the inflated period a given quantity of any of the leading farm products turned into money would at the same time have bought more lumber than at any previous period. Lumber, as a matter of fact, and largely on account of an abundance of timber has never in this country attained to selling values commensurate with its intrinsic worth. The public has been educated by events to esteem lumber too cheaply; to underrate its supreme importance and to remember its past degraded selling values. Incidentally, however, and apart from comparative and relative considerations, the prices of lumber had been forced upward by previous advances in the value of standing timber equal in many instances to a maximum of 800 per cent ; corresponding to the prices of necessary machinery and operating supplies, food stuffs and labor. When the panic came, all of these vital factors counted for nothing and prices of lumber precipitately tumbled to a level, in many cases below the actual cost line.

In spite of these undeniable facts, however, a strong public conviction had falsely been "shed abroad" by agitators that the country was in the clutches of an all powerful, relentless and voracious combination or trust. A populistic senator had declared these things with great particularity and vehemence on the floor of the senate, where he also moved the adoption of a joint resolution instructing the Bureau of Corporations to probe the whole matter and report its findings to the congress. The masses, for the most part ignorant of the facts, took the senator for a man of, at least, 
ordinary veracity, and naturally believing what he said, waxed indignant and assumed a militant attitude. Thus it happened that when the special session of congress convened early last spring to revise the tariff, the administration at Washington, the congress and the people at large were alike disposed and determined to make of lumber a special and sacrificial example. When soon thereafter a group of lumbermen eminent for conservatism, honor and intelligence appeared before the house ways and means committee and laid the matter bare, a change of sentiment began that resulted in not putting lumber on the free list as was the original determination, but in merely a reduction of the Dingley schedule for rough lumber of thirty-seven and one-half per cent, or from $\$ 2.00$ to $\$ 1.25$ a thousand feet. In addition to the outcome of the belligerent campaign above outlined, the Bureau of Corporations found its investigations bootless. The odious trust had eluded discovery, although lumbermen themselves had very generally and unreservedly aided in the investigation. The tariff agitation in this way proved a source of education without which the public would have remained in ignorance of the merits of the questions involved. The incident affords a powerful object lesson. Prior to this agitation nobody had taken any pains to acquaint the public with the facts and the masses, of course, were in a state of irresponsible ignorance of them.

The industry has undoubtedly suffered more from the combined ravages of the reactionary effect of the panic and tariff agitation and uncertainty than any other of the leading industries. The effect of the tariff upon the prices of lumber has never been and is not now tangibly discoverable. Agitators are in the habit of tracing the stimulating effect of the tariff on the prices of lumber and of glibly attributing robbery and wrong to its operation, but nobody in a position to see and know all about it has been or is now able to do either.

\section{International Trade}

The export trade of the lumber industry reflects its chief importance. Aside from the importation of tropical cabinet woods, there has been an average of possibly two per cent of the entire consumption of the country imported from Canada and that of a low priced character. This per cent was not materially increased under 
the Wilson tariff, which admitted rough lumber free. Perhaps it may be said appropriately in passing that the lumber industry has the same claim as other protected industries, and that if protection is right on general principles, lumber is and should be no exception to the rule. It has become axiomatic in lumber circles that the export trade automatically reflects domestic conditions. Importers on the other side are vigilant and quick to detect changes of market tendencies. If downward the latter are always exaggerated and made to serve as a dead weight. If upward, they are denied or discredited or minimized. Their own markets derive and assume the color and tone from and of conditions on this side. Hence it is not surprising that the export trade of the last two years has been especially unprofitable, although the volume of business has been less markedly shrunken than have average prices. The following tables, taken from the "Lumber Trade Journal," of New Orleans, exhibit the falling off in comparative valuations and average prices of wood exports as stated:

Unmanufactured $\ldots \ldots \ldots \ldots \ldots \ldots \ldots \ldots \ldots \ldots \ldots \$ 16,694,908$

Lumber $\ldots \ldots \ldots \ldots \ldots \ldots \ldots \ldots \ldots \ldots \ldots \ldots \ldots \ldots$ 36,189,226

Shingles $\ldots \ldots \ldots \ldots \ldots \ldots \ldots \ldots \ldots \ldots \ldots \ldots \ldots, \quad \mathbf{7 5 , 5 3 5}$

Shooks and cooperage $\ldots \ldots \ldots \ldots \ldots \ldots \ldots \ldots$ 14,084,29I

Doors, sash and blinds .............. 479,266

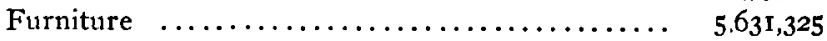

Miscellaneous $\ldots \ldots \ldots \ldots \ldots \ldots \ldots \ldots \ldots \ldots \ldots$ 8,366,754

Grand totals $\ldots \ldots \ldots \ldots \ldots \ldots \ldots \ldots \ldots \ldots \$ 1,52 \mathrm{I}, 305$

Decrease in total value, $\$ 13,653,873$, or 16.7 per cent.

Expressed in Standard Feet.

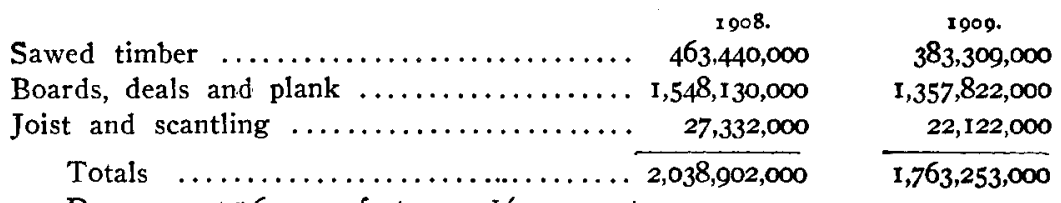

$\$ 12,580,389$

$29,435,493$

$6 \mathrm{I}, 784$

$14,060,712$

534,534

$4,293,904$

$6,900,616$

$\$ 67,867,432$

Decrease, $275,649,000$ feet or $13^{2 / 2}$ per cent.

Comparative Average Prices.

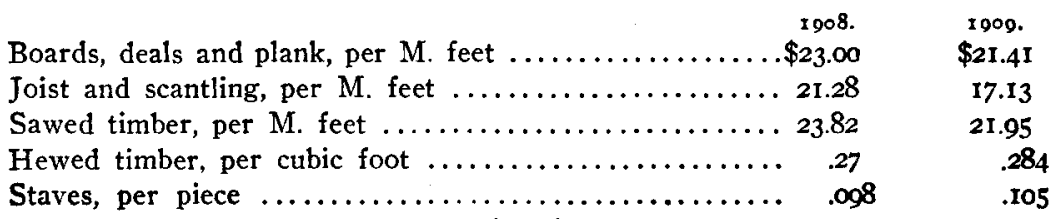


The comparative number of staves exported for the two years were respectively $61,696,949$ and $52,53^{8}$,016 pieces, most of which were shipped to France from New Orleans.

The principal importing countries include the United Kingdom, British North America, Belgium, France, Germany, Italy, Netherlands, Central America, Mexico, Cuba, West Indies and Bermuda, South America, Chinese Empire, Hongkong, Japan, British Australasia, Philippines, Asia and Oceanica, Africa. Great Britain is the largest importer. Exports to oriental countries largely come from the Pacific coast.

Co-operative efforts are in progress among gulf coast exporters of yellow pine products to reform and improve existing inspection methods on this side and to install representatives to guard against unjust reclamations on the other, the growing need of which has been impressed upon exporters by experience. The principal Atlantic and gulf outlets include Baltimore, Norfolk, Newport News, Brunswick, Savannah, Jacksonville, Pensacola, Mobile, Gulfport, New Orleans, Port Arthur and Galveston.

\section{General Outlook}

This is a branch of the general subject under review involving in a larger measure than the others matters of opinion or conjectural problems. At the present moment the producing capacity inherited from ante-panic stimulation exceeds the power of the country and the ordinary export movement legitimately to absorb. The fact is even now retarding price recovery and must be arrested before otherwise warranted advances can be made effective. The yellow pine industry, which in point of magnitude and importance leads all the rest, is extremely sensitive to market influences and is predisposed to fall upon the slightest provocation. Many habitually conservative, well informed authorities believe, however, that the industry faces another period of extraordinary activity and prosperity.

In this and other branches of industry not free to go into any agreement, other influences are in progress to induce individual producers to voluntarily curtail their outputs until the anticipated revival shall have been consummated. Building operations continue exceptionally active and railroad requirements are expected to undergo a large margin of increase. The crops afford promise of a 
heavy farmers' demand, and conditions in contributive classes of trade are believed to be of a character to justify an optimistic outlook.

The residue of standing timber in the country is being exhausted at a rapid rate, the amount destroyed by fire, storms and vermin being estimated at about one-half of the whole amount used in industry. The latter is estimated at about $40,000,000,000$ feet annually. One important factor the industry is now facing and must reckon with is the enormous substitution of other materials for uses formerly monopolized by wood, notably steel, iron and cement. The life of woods exposed to the weather is also being increased several fold by artificial preservatives. Upon the whole, the popular propaganda of a rapidly approaching timber famine is very considerably exaggerated and the present generation need not be greatly alarmed. 